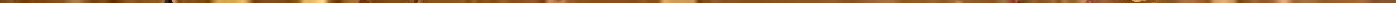




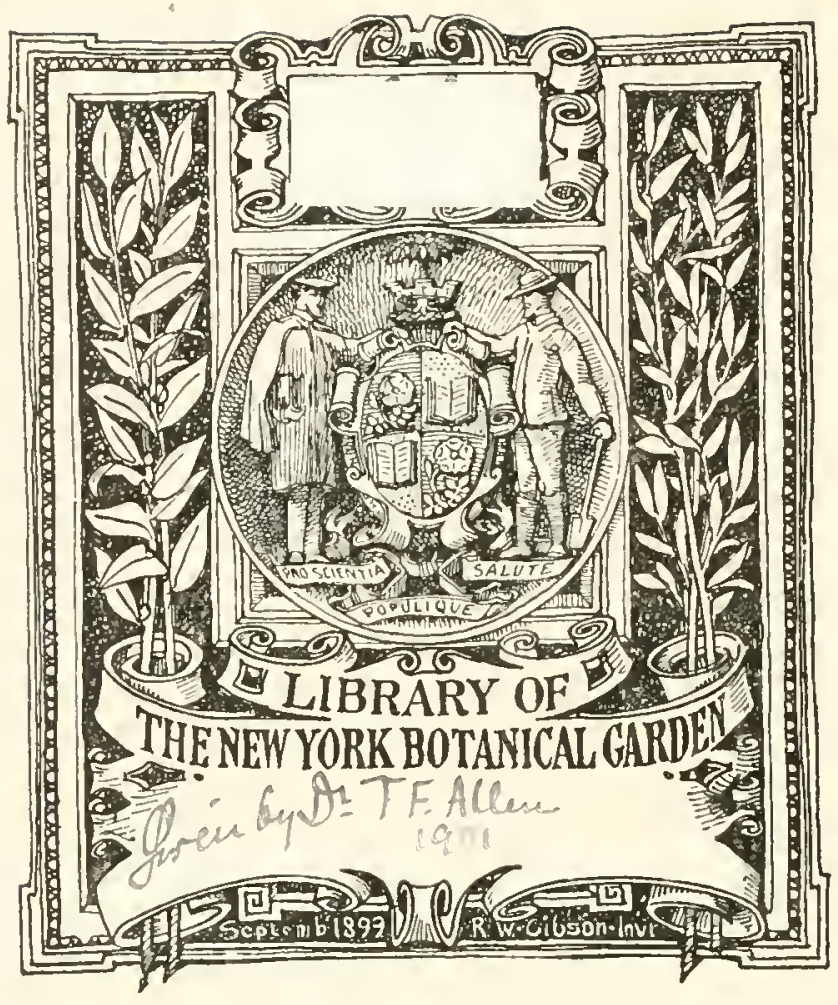









\section{UNIVERSITY OF NEBRASKA. \\ FLORA OF NEBRASKA. \\ Published by the Botanical Seminar.}

\section{PART TT.}

\section{COLEOCHAETACEAE, CHARACEAE.}

ISY

Alemet F. Woons, M.A. 



\section{Branch III.-CARPOPHYTA.}

Nulticellular plants; plant-body, for the most part, a parnehymalous ticsure aserger

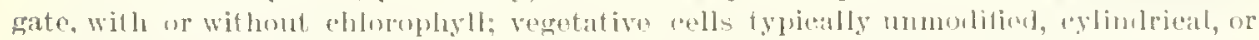

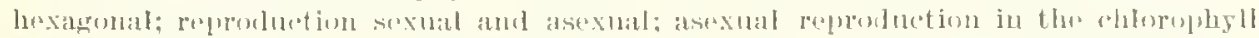

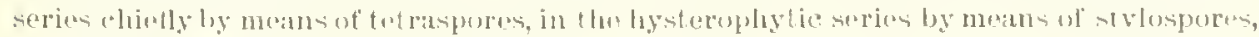

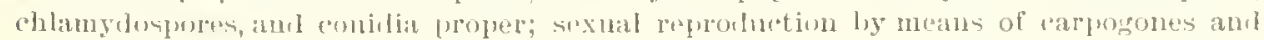
antlerili, resultiug in the formation of a sporrearp.

Chinfly marine lobophetes, or terrestrial hystemphyles, Plant body an unlitfer

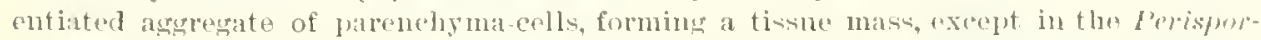

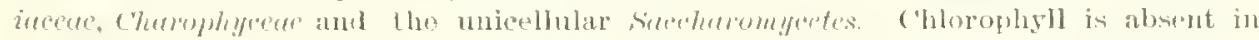
most of the origers. When present, it is often more or lass misiken by other substancess,

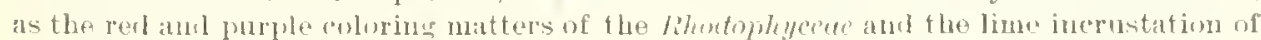

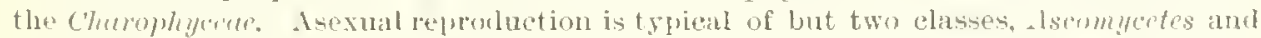
lihomplyane. In the former, it results hy means of comilia, stglospores. and, more larely, hy chlamplospores; in the latter uniformly by means of tetraspores. 'The fertiljzation of the carpogone by the entents of the antherid, 1 spienlly through the modium of at trichogyne, produces a so-called sporocarp, which is characteristic of the branch. In the Chronghycece, howerer, the fertilization doos not result in the formation of a sporocarl. In the hysterophytes, moreover, hasuality decreases with the distauce frum tho point of derivation of the gromp until it tinally disappears, but at the same time without a corresponding moditieation in the prosluetion of the sporocarp.

The rulationsips of the carpoplytes are varied, and their inter-relations somewhat obseure. Throusl the holophytic serios they comect iu a nearly straight line, the Phyeophytes with tha Bryophytes, notwithstanding the evident hreak at tho beginning of the series. On the otber lanil the hysterophytic series, which and blin lly at thu upler "nd

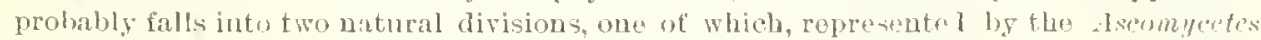
aud busidiomyetes, has perbaps had its origin in or near the bromosporeren, while the other represented by tho culoulbenimeren, etc., has its derivation and relationship still involved in great obscurils.

\section{Class III.-COLEOCHAETEAE.}

Small graen plant (rowing attached to submergen stems an: loaves; thallus com posed of branehed rows ul cells more or less united laterally into a that, irrugular or circular disk. Reproduction by sexually probucel carpospores and asexual swarm-spores (zongonidis),

The terminal cell of a branch which is to prolnce a carpospore swells, and tho upper portion elongates into a narrow tubular process (triehogye) which opens at the top At the same time antherids duvolop from certain cells as small flask-shaped mitgrowths. usmally three or four from a eell. Each antherid thus formed cuts off from the mother-cell by a transrurse wall, and the contents form a single biciliate antherozoid, which escapres and finds its way to the femole ell, probably through the trichogrne. After fertilization, the female cell forms a wall aromd itrell insido tho old coll-wall, and the wholo hecomes envelnper by a coatine of exth whieh erows up from below, thus forming a sporocarp with a singlo carpospore. 
The Coleochaepere are related to the Ordoymineres on the one hand and to the Fln:ideun on the uther. It is possible also that the oriun of the great aroups of the higher fungi is to be fourl in sone snch yroup as this. The nature and signiticance of the process of the formation of the sporocarp of the higher fungi has heen a frnitful cause of discussion. ahd it has been commonly thought of tate that it had no relation to tho earpospore of the colencholfae, or to the oospore of the l'lycophytos, hut was rather homologons to the asexual spore-formation of the lower fungi. But the fuboullenincerce. which according to recent inrestigation exhibit asexuat reproluction of the same type as the Colmoluepere and Floridenc. indicate that this riew is erromeons and that the origin of the higher fungi is to be sought in about the same place as that of the tast namerl groups.

There is but one order and famils:

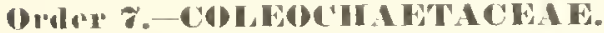

\section{Family.-COLEOCHAFTACEAE.}

The characters of the class. There is but one genus. A second one-Chnetop"lfis is thought by some to hetong here also. It is distinguisher from cincuchete by the production of $2-4-5$ swarm-spores in each spore mother-cell insteid of a single one as iu coleocluate.

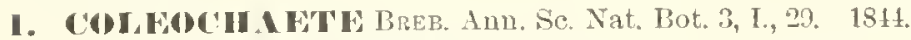

The characters of the tamily.

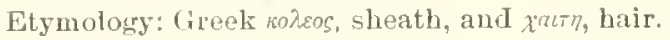

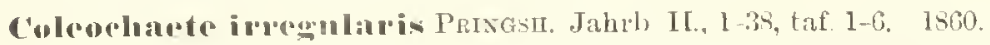

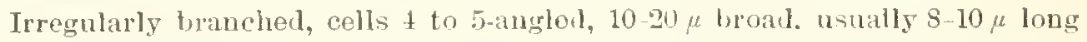
or sometimes twice as loner as wide; carpogones $10-60$ p in diam.

Grows in noro or loss extended irregular sheots closely alliering to the sulystratum. The cortication around the carpospore is sometimes only partially developed.

On Lemme ani chara spp. from Cherry county, and on Nitella from Minden. Pt. XXIII., Fig. 3, xion.

Coloorluacte grutata Breb. l. c. t. II.

Thaltus lat, bright green, $5-2 \mathrm{~mm}$. in diam., malle up of dichotomonaly branchod fitaments united in a mol* or less lobed orbicular disc; cells thick-walled, 4 -5-angled or rounded, $1317 \mu$ wide, 10 to $\mu$ tong; carposporo suluglobose, 85- $100 \mu$ in diau.

Extremely variahle as to size and shape.

On Chure from Cherry county. Plate XXIII., Fig. 1. x100,

Colombarto molomlanis Prisgsir. l. c.

Whathe like that of $C$. seutulu. but regularly orbicular, not lobel, .5-2 $\mathrm{mm}$. iu diam., cells usually isodiametric, 11$)-17 \mu$; lruit as in $($ 'scutatu, lout not so olfen fomm as in that specios.

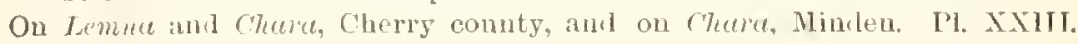
Fig. ‥ x100.

This species is probably only a variety of $C$. seutula. 


\section{Class VI.--RHODOPH YCEAE.}

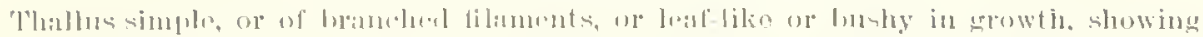

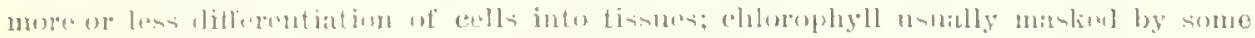

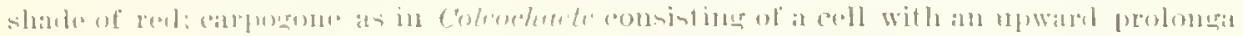

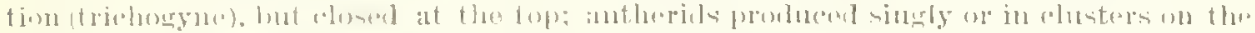

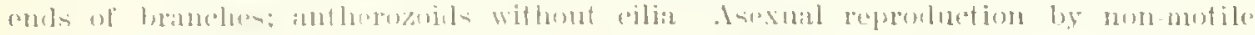

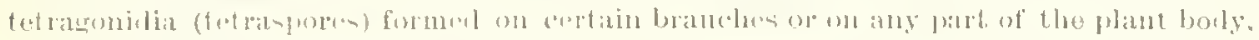

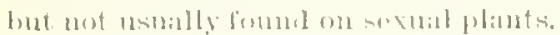

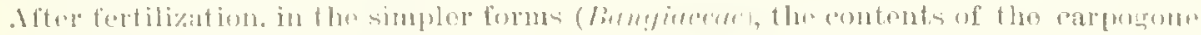

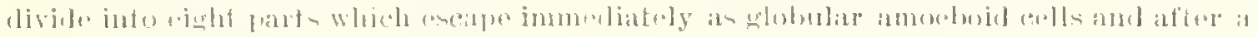

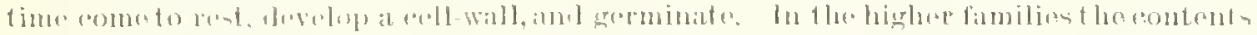

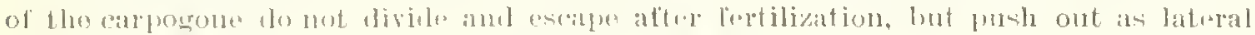

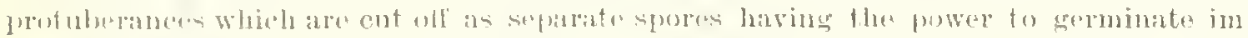

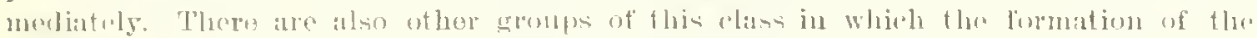

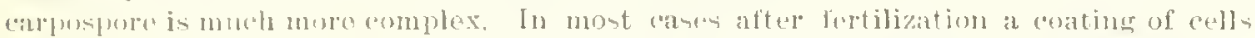

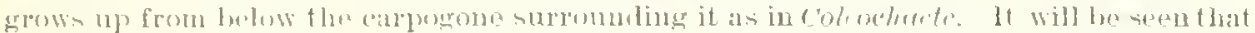

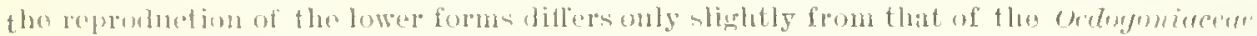

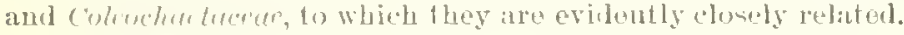

'There in lint wre order.

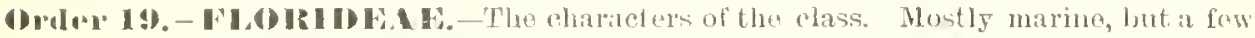
spregen whlely distributel in flush water.

but one fimily is represented in onr limits.

\section{Family.-NEMALIACEAE.}

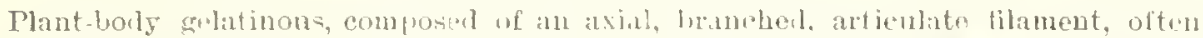

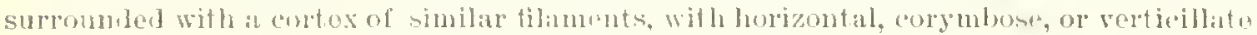
branches on which are borme the antherils and rarpungues.

\section{sivolsis}

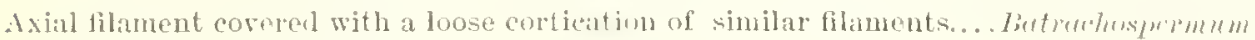

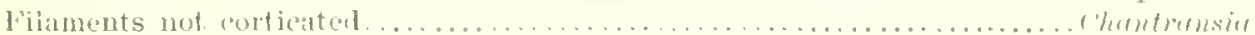

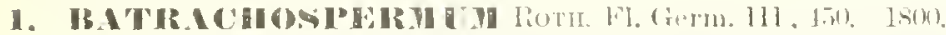

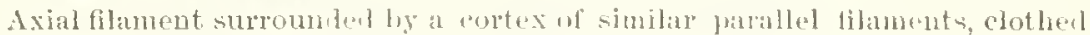
with subglobose whorls of luanchlets on the cuds of which are borne the carpogonms and antherids.

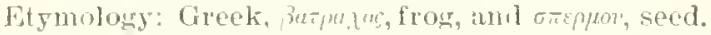

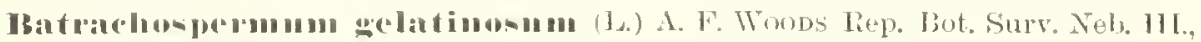

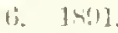

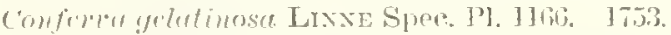

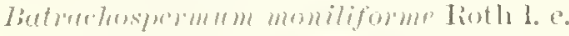

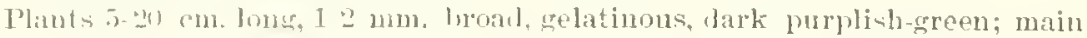
stoms ant branches romposenl of an axial, articulate lilament corereal with a loove cont (eonteation) of similat lilaments from which arive at more or less regutar intervals lense globular whurds of monitiform, dichotomously divided branchlets.

In springs, bellevue. 
Plate XXIV., Fig. 1, a portion of the plant body xio; Fig. 2, r branehlet xə̄o); Fig. 3, branchlet with antherids; lig t, branchlet with soung carpogone; 17.5 .5$. carpogone with ant herozoids (corpuseula) attached. The carpospores have dereloped and cells from below have started to grow np around them, thus forming a sporocarp. (Figs. 3-5 after Bornet and Thuret.)

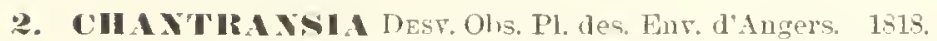

Plants growing in tufts, bluish.green or violet, filaments irregularly branched, composed of a single series of rylintrical eclls, not corticated; antherids one-celled, on the euds of short, clustered branches; carpogones at the ends of similar branches.

Etymology: dedicated to Chantrans.

This genus is of doubtful position. It may be placed in any one of several of the lower families of the Floritene. Many of the fresh-water species have been shown to be early stages of plants belonging to other well defined genera, as Butruchospermm, Lomuneu, etc.

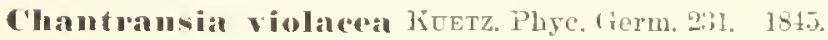

Plants $1-2 \mathrm{~mm}$. long, arising from a thalloil mass of cells; filaments not greatly branched; cells $5-10 \mu$ wide, $\overline{5}-8$ times as loug as broad; branches fastigiate; fruit on short, cylind rical branchlets.

Bellevue, with Butruchospermuin gelutinosum.

Pl. XXIII., Fig. 4, a portion of thallus with filaments arising. $\mathrm{A}$ and $\mathrm{B}$ fruiting branches.

\section{Class VII.-CHAROPHYCEAE.}

Slender, snbmerged, aquatic plants, from a centimeter to a meter long, with monopodial racemose branching and rerticillate leaves; stems rising in tufts or mats from the substratum to which they are fastened by slender rhizoids; sexual reproduction by means of carpogones and antherids. prodnced monoeciously or dloeciously in the axils or at the nodes of the leaves; as xual reproduction by means of stmited branches.

These plants are rich in chloroplyyll, though this is sometimes masked by a thin coating of carbonate of lime, giving them an ashy-green appearance and making them rery fragile.

The stems and branches are made up of a single row of long, eyliucl rical cells placed end to end. The leaves arising from the nodes are of the same structure. Around the axes there may be developed a coating of long tubular cells (cortication) parallel to the axial cell. The sexual organs consist of more or less globular carpngones and antherids, produced monoeciously or diveciously in the axils, or at the node's of the leares. Each earpogone consists of a singlo, large, spirally corticated coll which after fertilization becomes a carpospore. The globular antherid is mate up of eight "shields," within which is ultimately produced on each shield a tuft of filaments, each cell of which produces a spirally coiled, bieiliate antherozoid.

The carposporo in garmination produces a simple plant, the so called pro-embryo, consisting of a single row of cells with limited apieal growth. The sexual plant arises from this as a latoral branch.

The close relation of the Ranginefur among the lower Floritene with the Oedogoniuceue and the Coleochurtere has alreaty been remarket. There is no essential point in the reproduction of the cherophyche or in the strueture of their llint-body that differs 


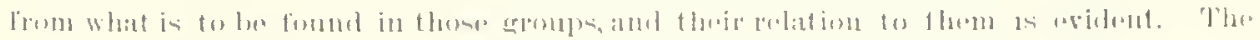

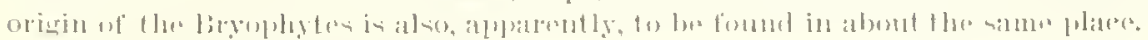

the elace (o)

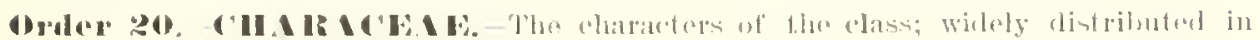
fireh and lorackish watre.

\section{i $101 \times$}

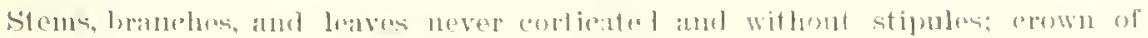

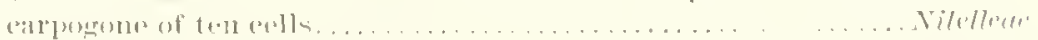

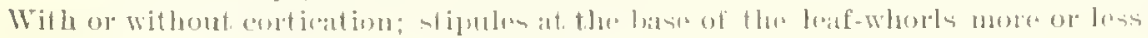

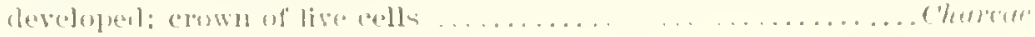

\section{Family. NITELLEAE.}

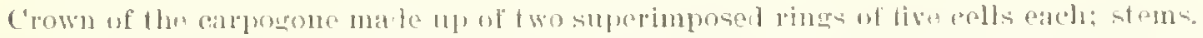

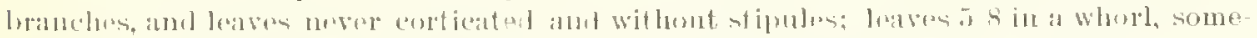

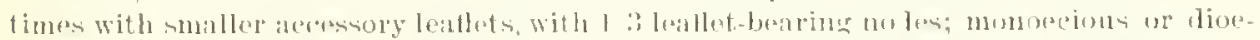

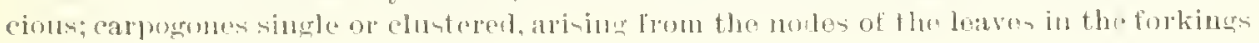

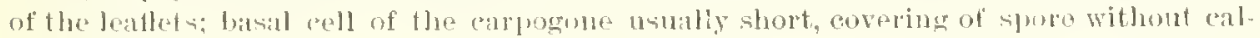
carrous layer.

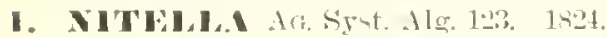

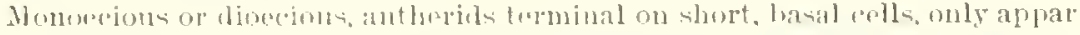

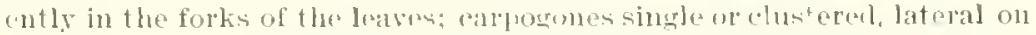

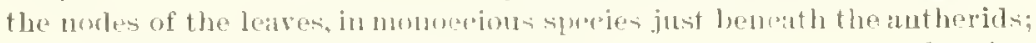
crown 10 eelluh; leaves with several soments, but only l leatlet-bearing norle; loatlets often lepeaterlly dixidert.

Ftymoluer: Latin niteo, shino.

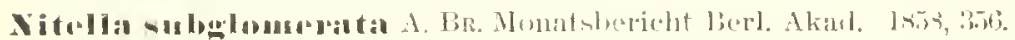

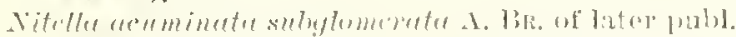

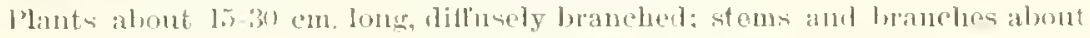

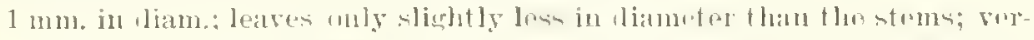

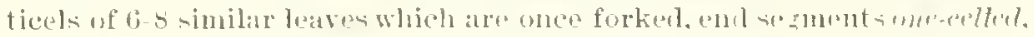

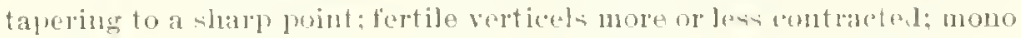
ecious, fructitication not enveloper in jelly; anthorils uplobular, 270 $300 \mu$ in liam.: carpogmes often clustered below the antlurits; spores

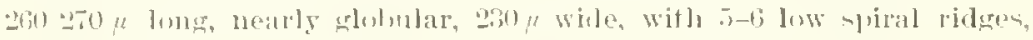

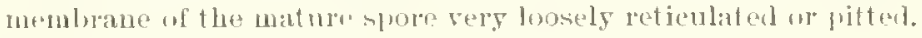

Mimlen, Tork.

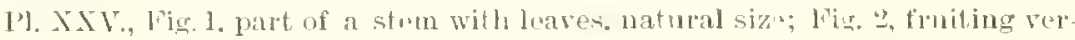

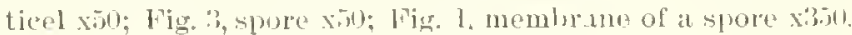

Nitalla Ilavilis (I.) Ar. Syst. Aler. 121. 1524.

Chume llowilis L. Spee. Pl. 1157, 175 ;

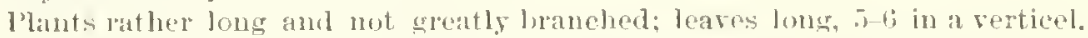
each liviled into 1-1 terminal leaflets with ronude:l of short-pointest

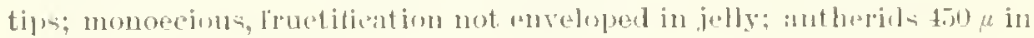

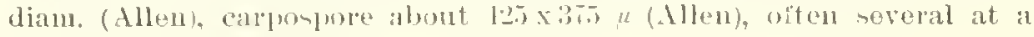
noile, crown evanment. 
Somutimes resembles $\mathrm{Y}$. subylomerotu in general appearance, but may ive distinguished by its larger autherids amol carpogones and by the bluntish or short-pointed leares.

Mindin.

Pl. XXYT., Fig. 1, 1 a, branches, natural size; Fig. 2, 2 a parts of Jeaves showing antherids and carpogones.

Nitella opacal Ar. 1. e.

Plants $10-20 \mathrm{em}$. Iong $(5-30 \mathrm{~cm}$., Alleu $)$, not gleatly branehed; rerticels of $6-7$ leaves ustally diviled into 2-3 terminal une-eelled leatlets, abrutly sharp-pointed or bluntish as in $\mathrm{X}$. fheritis, which this species resembles very mueh in lobit; fruiting verticels contmeted, though not so much as in $N$. sulylomeratu; dioedions, organs of frutifieation not enveloperl in jelly; antherids variable in size, Istully large faccording to dllen sometimes $890 \mu$ in diam.). carpogones $1-3$ at a $\mu$ ode, crown evanescent, spore $30036011240-300 \mu$ (Nigulat).

The dried junts are dark-colored and somewhat opaque.

In Deadman's Finn, Lincoln.

Pl. XXVII., lig. 1, part of a plant natural size; Fig. 2, part of a fruiting verticel $x 50$; Fin. 3 , spore xito.

Nitellat uncomuata A. lik. Selnweiz. Char. IRt7.

Chume mueronetu A. Br. Ann. Se. Nat. Bot. 1, TI., 33̈]. 1834.

plants ahout 5-20 cm. Iong, branching freels, usnally 6 Ipares in a whorl, primars leaves banehed into 25 secondary leallets, thome again branched into 1-3 ultimate $2-3$ celled segments, end-cell nueroniform; monoecious, fructification not enveloped in jelly, fruit usually in all the divisions of the leaves; carpogones single or aggregater, spore 270-380 $\mu$ (Nordstodt), crown persistent.

This species maty bo easily distinguished from the other Nobraska species by the repeatedly branched leaves with muroniform tips.

Mimden.

I'l. XXVIII Fig. 1., part of plant natural size; Fis. "2, lixuiting rerticel x50; Iig. 3 , spore $x 50$.

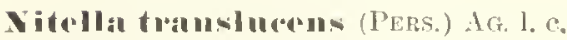

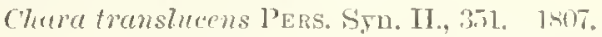

Plants rather large, 10-40 em. Inish, not greatly branched; whorls of sterile leaves 5-6, undiviled, large, 1-cellet, terminated by 4 2-celled, mucrouate tips; fertile verticels contracted ints small hearls, $1-1 \mathrm{~mm}$. in cliam.; usnally axillary, sometimes terminal. primary luaf $1-3$ times diviled into 4, ultimate leatlets 2 -eelled, end-cell mucronate, 95-126, $\mu$ long, 32-12 $\mu$ wido at the base, point thick-walled and sliarp; monoecious: carpogones 1-2 at a node; spore 2:0-970 4 long, nearly as whle as long, dark-linown, witl 5- 6 scarcely frominent riclges, membrane of the spore closely reticulated.

York. The froiting verticels of this plant are rxatly like those deseribed and fignred log A. Braun in Nordstedt linsm. is N. arillius A. LR. But the spores of $N$. rexilluris are sairl to bo $20.310 \mu \mathrm{Img}$.

Pl. XXIX. Fig. 1, plant uatural siza; Fig. "2, fruiting verticel x.50; Fig. 3, spore x50; Fig. 4, membrane x350; bigs. 6 and 7 , entlecells of leaves x50.

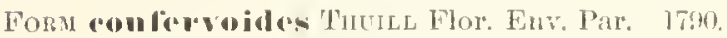

Plauts very much smaller and more branched than tle tspe; main stems only $270 \mu$ in diam.; ladves and leallets in wholls of $1-5$, usually 1 ; primary seg- 


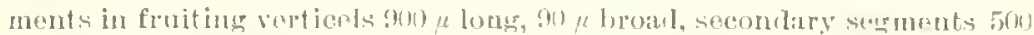

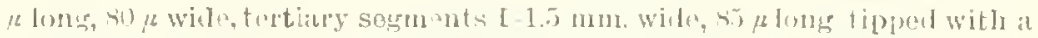

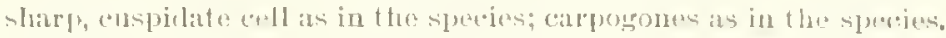

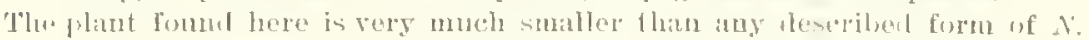

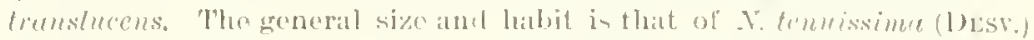

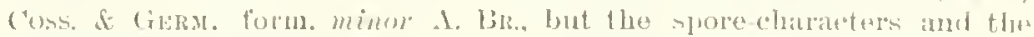
structure of the mueronate cells of the leaves slow undoubted connece tiun with $x$. trenstucrus.

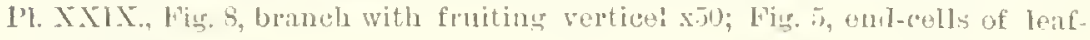
let x:350.

[ToLYPELL has tho general hatit of Nitelte, from which it maty bo distin-

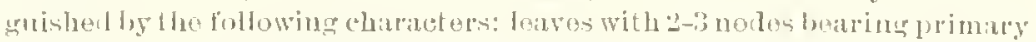
lrallets, always monerecious, antheriels lateral, often with homis batal cell.

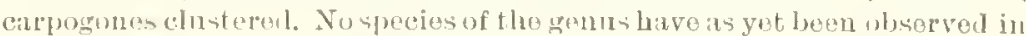
Nobraska, but from the reportod distribution of several of them it is likely that some will be found.]

\section{Family. CHAREAE.}

Crown of the carporone mate up of fire edls; stems and leaves with or without corti ration; stipules at thr base of the loaf whorls, more or less deweluped, one-celled; haven 615 in a whorl; carpogones and an lherids on the npper sides of the leaves, spore usually coated with a caleareous haver.

The family contains four sonerd, of which only one is here represented.

1. CIIIIRI L. Sp. P1. 1150. 175\%,

The ronaterers of the family.

Etymology: ireek yapn, juy.

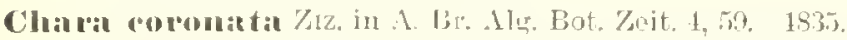

Plauts usually large, from a few centimeters to a meter long, short forms "tsnally much hrancher with firm, broad stems and leares, 1-1.5 mm.; loner forms with eefli low lirm and narrower, no contication, stipmles at the baso of the leaves forming a simple whorl; teaves long, 3 In cells, ending in a crown of :3 5 nucronate cell $;$; monoecions, cappogones and antherids

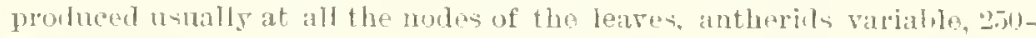
$300 \mathrm{~h}$ in diam., curpogines variable, crown larga. cells rather loum, usnally sprealing, sumetimes connivent; spore 15/-500 u, black, bracts extrmety rariahle, from very much shorter than the carpogrone to three times as long-quite variable on the same plant.

Common all over the state.

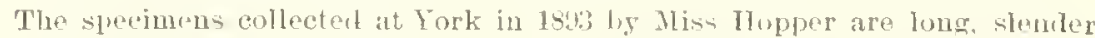

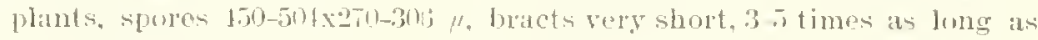
widu, acuminate, teares 3-6elled Pl. XXX., Fig, 1, part of plant natural size; Fig. 1, earporone x.5). The specimens in the herbarium of the Dontanical surwey from Clerry eounty ani from Greeuwool are larger

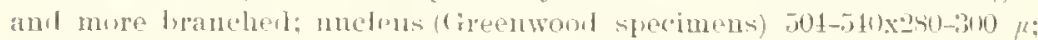
brants 1-3 times as long as the carporone; (Clerry eounty specimens)

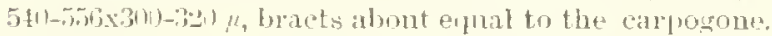

Pl. XXX. Fig, 2-, part of plant, natural size: Fis. 3, nole with carpogones xio: Fig. jom somg carpougones and antherids xin; Fig. 6. stem with bases of leares showing stipules $\times 2.5$; Fig. 7 , end-cells of leaf $x \overline{0} 0$. 


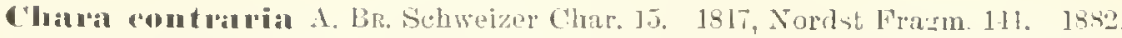

Plants rather long, :0-10 cm., not greatly brancherl; braches usully shart; stems and branches corticated; cortex-cells twice as many as the leares in the whorl next above; primary (or spine-bearing cortex eells) nsually most Irominent; stipular whorl louble; stipules ultimately falling off, leaving two rows of sears; leaves 6-10 in a whorl, variable in length and number of corticated norles. lower no le always corticated: encl-cell of the leaf not corticatel, short and obtuso; whorls often remote; monoe. cious, 1-1 fertile joints; antleride small, 300-321 " in diam. (280-350 Migula); carpogones large. 900 " long: crown short and blunt; spore $500-612 x 370-350 \mu$; dark brown: 10-11 striate; braets nsually shorter than the earpogone.

Fremont, louds in Cherry county: Ponca river, Boyil county.

May be distinguished from $\mathrm{C}$. foctilu by the larger spore. Accorling to $\mathrm{HI}$ grala the spores of $C$. fortilu are never longer than $550 \mu$ and those of C. contruriu never shorter than iso $\mu$.

Pl. XXX1.. Fig. 1, part of a plant natural size: Figr. 2, part of stem showing ecrtication, leaf whorl, and stipular whorl xĩo; Fig. 3. part of leaf showing maked rnd cells and two fertile corticated nodes x50; Fig. 4, cross section of slem $x 50$, (a) young spine.

Clual ra foetidal A. Bro Anu. Sci. Nat, Bot. 1, 11, 35t. 1\$3t. Flora 1835, p. 63.

General habit like C. contruciu, but more branched and leaf whorls-less remote; stens and hrancles corticated; cortex-colls $t$ wice as many as the luaves in the whorl next abure; primary (or spine-hearing cells) asually leso prominent than secondary cells; stipular-whorl donlyle and prominent; stipules presistent for some time and not blunt as in co contrurire leaves 610 in a whorl, with 1 lo several corticated nodes, and 1 or more naked ones; end-cell of the leat acute (not blunt as in $C$ contreriu); monnecioms; 1 - fertile joint ; antherirk ahout 350 in diaur ; carpogones smali; crown short. blant: spores $485540 \times 370350 \%$; dark brown; 10-14 striate: - Iracts at fertile joints longer than the carpogone, and the same ]ength or shorter.

Variations in the length of the bracts and the levelopment of spines give several forms:

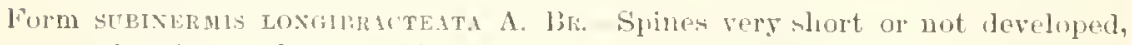
bracts very longs, $2-4$ times the length of the carpogone.

Pumplusers] areek, ('heyenne connty; limball; Cherry eounty; Ponea river, lioyd comnty.

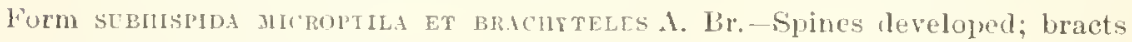
shorter than the carpogone; encl-seguent of leaf short.

Buffillo creek, llatigler

Form scbinspida macroptidi et manoteles. A. Bro-Bracts longer than the fruit; curd-segment of leaf lons.

Cherry iounty.

In. XXX11., Fir. 1, plant natural wize: Fig. "2, part of stem slowing ono entire leaf and the bates of tho other leaves of a whorl the leaf bent in orter to gen it on the plate), $(u)$, stipules, (b), spines; ligm. 3-4, cross sections of stem, 3 a, spine coming from primary cortex cell $x 50$. 


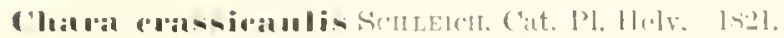

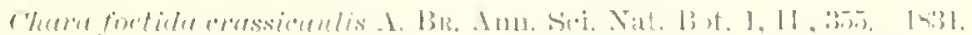

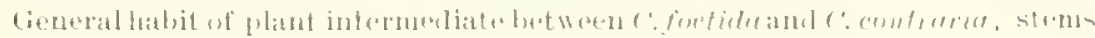

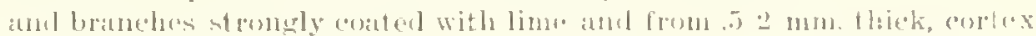

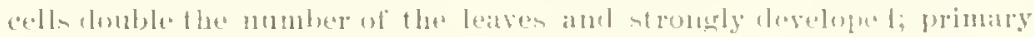

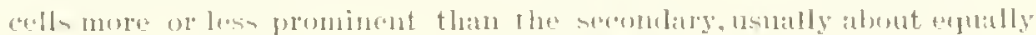

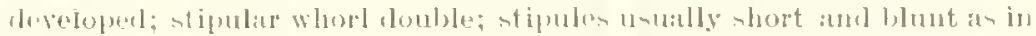

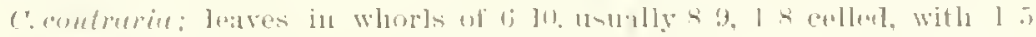

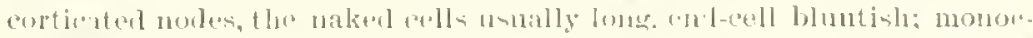

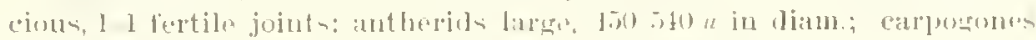

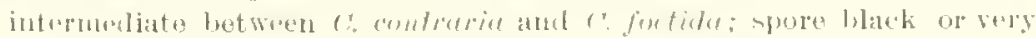

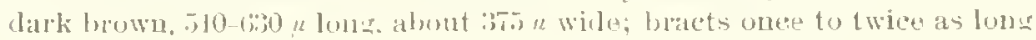
as carpogrone.

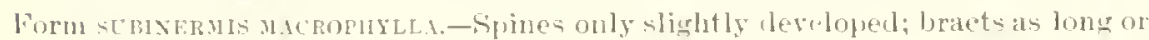
twice as long as lle fruit ; leaves ustally long.

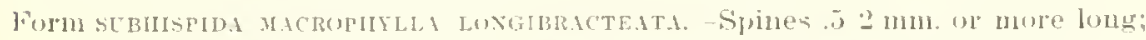

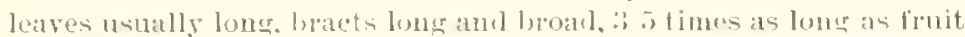

The forms, especially the last, more common than the type; usually growing towether.

l'ine lidge (type and forms mixeit). Hitigler form 2).

1'l. XXXII. (form 2) Fiz. 1. part of planl uatural size: Fig. 2, part of stem

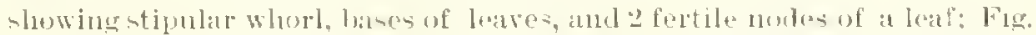
3. carpugoue with spores: ligs, $t \bar{j}$, crons section of stem, $\bar{j}$, a, b, spines growing from primary cortex aells. xiso.

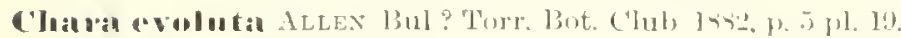

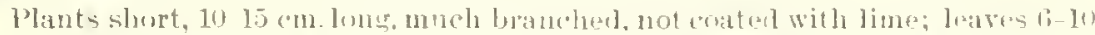
in a whorl. whorle nmmerous $t$ i enricated uoles and two short nakerl noles; rut-cell anminate. corticating cells ahout the same number as lenves, secondary cells more or less internixed; stipular whorl louble: stipules long; spines long. numerous, nunty in fascicles of 22 3 ; monoe.

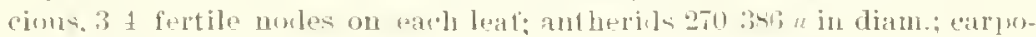

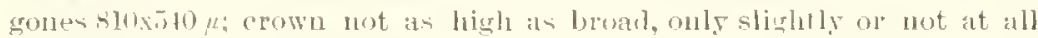

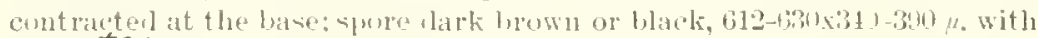
about ingre or lens lintincet striae.

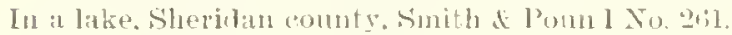

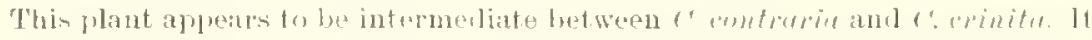

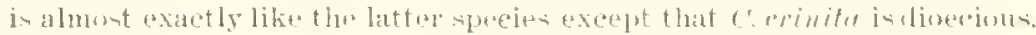

P]. XXXIV., Fig. 1, part of plant natural sizan; Fig. "2, purt of stem whowing bases

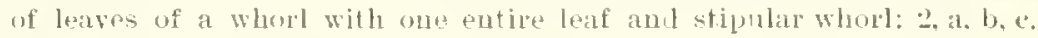

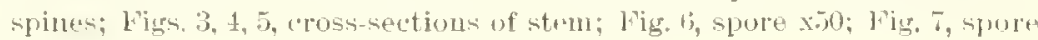
$\mathrm{A} 7100$.

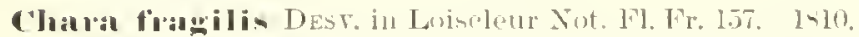

Flants long and slender. rather rigid; stems ex" limes as man ac laves in whorl next abore; stipular ring lonble, stipules very shout; leares loug and pointed, is sorticated senments and oue or two shorl, naked suguents at the end; end-cell pointed: 1 -9 leaves in at

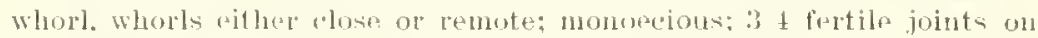

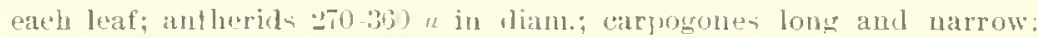
crown 15020 h higl as broal as high; spore dark brown, nearly black. 
$630510 \mu$ loug. abont 360 " broul, severul sharp prones at the base; buets at the fertile joints variahle in length, ustially somewhat shorter than the carpogone.

Whitman, lakes in central Cherry county,

Pt. XXXY. Figs 1, 1 ia, parts of plunts natural size; Fig. 2, part of stem showing bases of leaves of a whort aud two fertilo nodes; 2 b, stipmlar whorl; 2 a. remainder of leal show in 2; Fig. 3, carpogone containing spore; Fig. 4, cross-section of stell, x50.

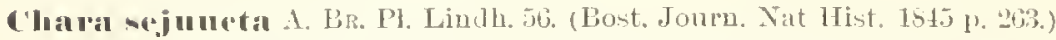

General habits of $C$. frogitis; stem triply corticated: leaves long, in whorts of 5-1:2, with 6-10 segments, the lowest ol hirst semment slort, unt corticated, all the others corticated, last segment tipped with several short spines; stiputar whor] well developed, of 3 series of stipules, spines on tho stem short aut sharp; monoecions, hut antherids and earyogones borno at different joints, not together; antherids abont $380-380 \mu$ in diam.; spore of carpogone 630x360 $\mu$, crown of long, nurow cells spreading or conuivent. Minden.

1'1. XXxVI., Fig. 1, part of plant natural size; Fig. 2. part of stem showing lower naked segments of the leaves of a whorl and stipular ring, :2, a, b, c, leaf with fertile nodes; Hig. 3, cross-section of stem, 3a, spine, xjo. 


$$
\begin{gathered}
\text { DESCRIPTIVE } \\
\text { PLATES TO PART } 1] .
\end{gathered}
$$


PLATE XNIII, Xllo.
Fig. 1
Coleodurete sentatis
..

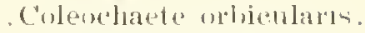
" :
Coleochate irregulario.
$\therefore 4 \times 3.0$.
Clantrausia violacea.

1. B. foniting hraturhes. 

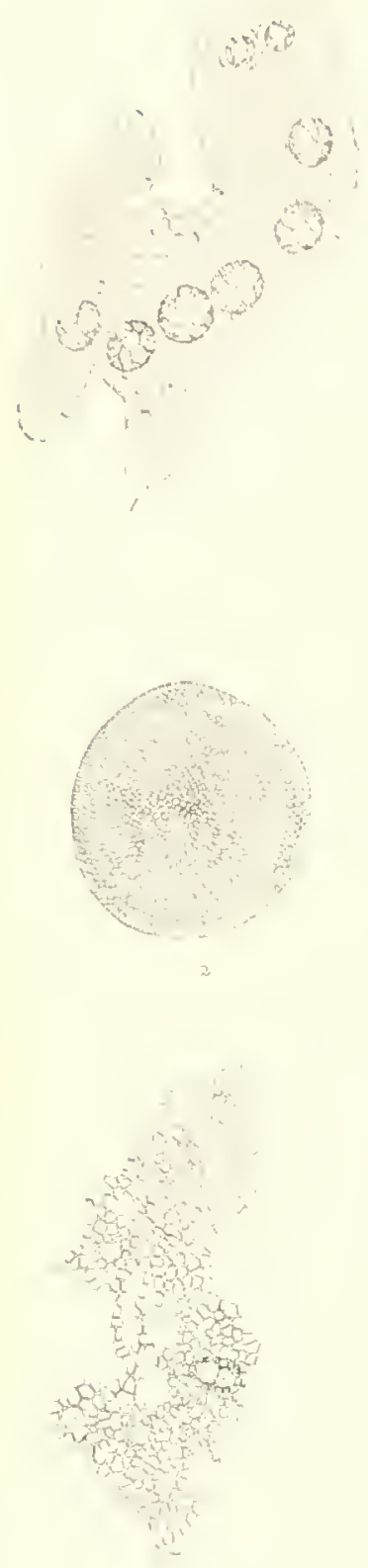

\section{1}


PLATE XXIY.

D.ITRAOIIOSPERMT'H GEL.ITINOSL H.

Fig. 1, Portion of plant body. x.

- Branchlet. x-no.

"3, Branchlet with antheridia.

". t, Branchlet with young "arpogone.

. 5, Carpogone with antherozoids. 


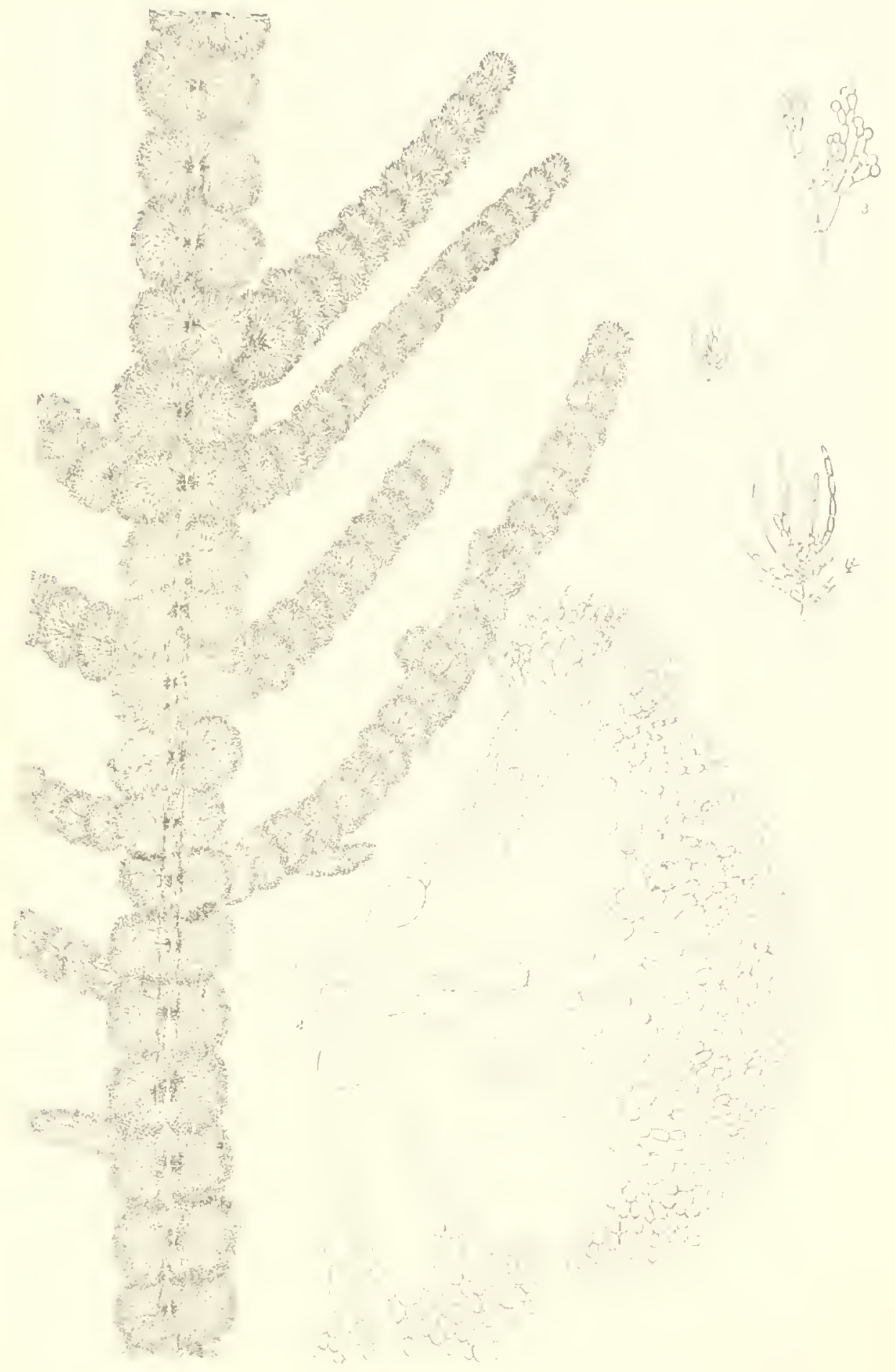


PLATE NXV

YITELL I MEBGLOMERATA.

Fig. 1, Portion of item. natural size.

- 2 Fruiting verticel. xu?.

* :3 spore. xü.

. 4 Nenbrane of spore. x3so. 

PLATE XXVI.

NITELLA FLENILIS.

Fier. 1, 1 1 , branchen, natural size.

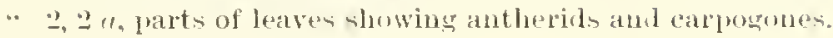

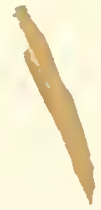



PLITE XXVII

NITELL I OPAY'

Fig. 1, Part of a plant, uatural size.

2 Part of a fruitiug resticel. xint

:3. Singre. xits. 

PLATE XXYIII

NITELLA MECRONATA.

Fige 1. Part uf a plant, netural aizts.

$\therefore \quad \because$ Frniting vertienl. xio.

.. :i. suore. xit

.. 4. Membrame of spure. xis, 
A 
PLATF XXIX.

XITELLA TRANSLLCENS

Fig 1, Plant, natural size.

". Fruiting verticel. xo

.. S. Spore. 50 .

" 4, Nembrane of spore. x330.

"6, 7, End-cells of leaves. xis.

Forma remferverides.

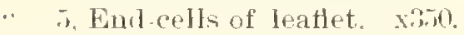

* 5 , Branch with fruiting rertices. xis! 

PL.ATE XXX.

CIIARA CORONATI.

Fig. 1, Part of plant, natural size.

". ". Part of plant, natural size.

* 3 Nole witl carpogones. xin.

* t. cirpugone. xĩ).

". is Young (arpogunes, and antherids. xin

* f, stom with bares of leaves, showing sipules xus

“7, Endrello of heaf. xin. 

l'L.S'H XXXt.

('HARA CWNTRARIA.

Pir. l, Plant, natural size.

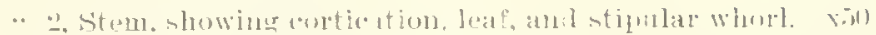

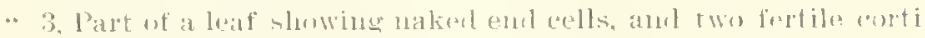
eated unlen. xis.

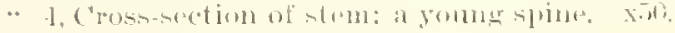





\section{PLATE XXXII}

(HIRA FUETIDA SEBIISIIIA MAGROPTILA.

ligr. 1, Plant, nataral size

-. ". Part of stem, showing one entire leaf, aud the hanes of the

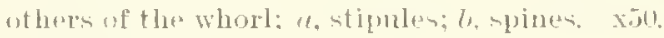

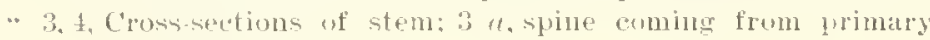
cortex-cell. xis! 

PLATE XXYII.

CIIARA CRASEICATLIS SLBLISPIIA LONGIBRA.TEATA.

Fig. 1, l'lant, natulal size.

" "2. Stem, showing stipular whorl, bises of leaves, ind two fertile undes. xio.

* 3, Carpogune with spore. $x=0$.

- 4. 5 , Cross-sections of stem; $50, h$, spines growing from primaly (n)tex cells. xor). 



\section{PLATE MXXIV}

(IIARA ETOLITI.

Fig. 1. Plaut. uatural size.

-. 2. Stem. showiug bases of leaves of a whorl. with one ent ire leaf and -tipular whorl: 2., ". h. -pines. x.ju.

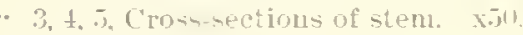

6. Sporr. x.30.

. T. sprore xl(n). 



\section{1'LATE IXXY.}

IIIIRI FR.ITILIS.

Hige. 1. 1 a, l'arts of plante, natural size.

2. Part of stem, showing baste of leaves and two fertile noden:

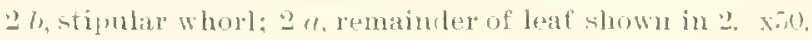

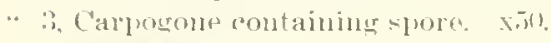

* I. Croms-section of stem. xinl). 



\section{PLATE XXXYI.}

("HAR.I SEITNC'TA.

Fig. 1, Plaut: natural size.

"2. Stem, showing lower nakel segments of the leaves of a whorl, aul stipular riug (s. s.): 2 " , l, c. leaf with fertile uodes, xino.

.. 3. Cross-section of stem; :3 " spine. xal!. 































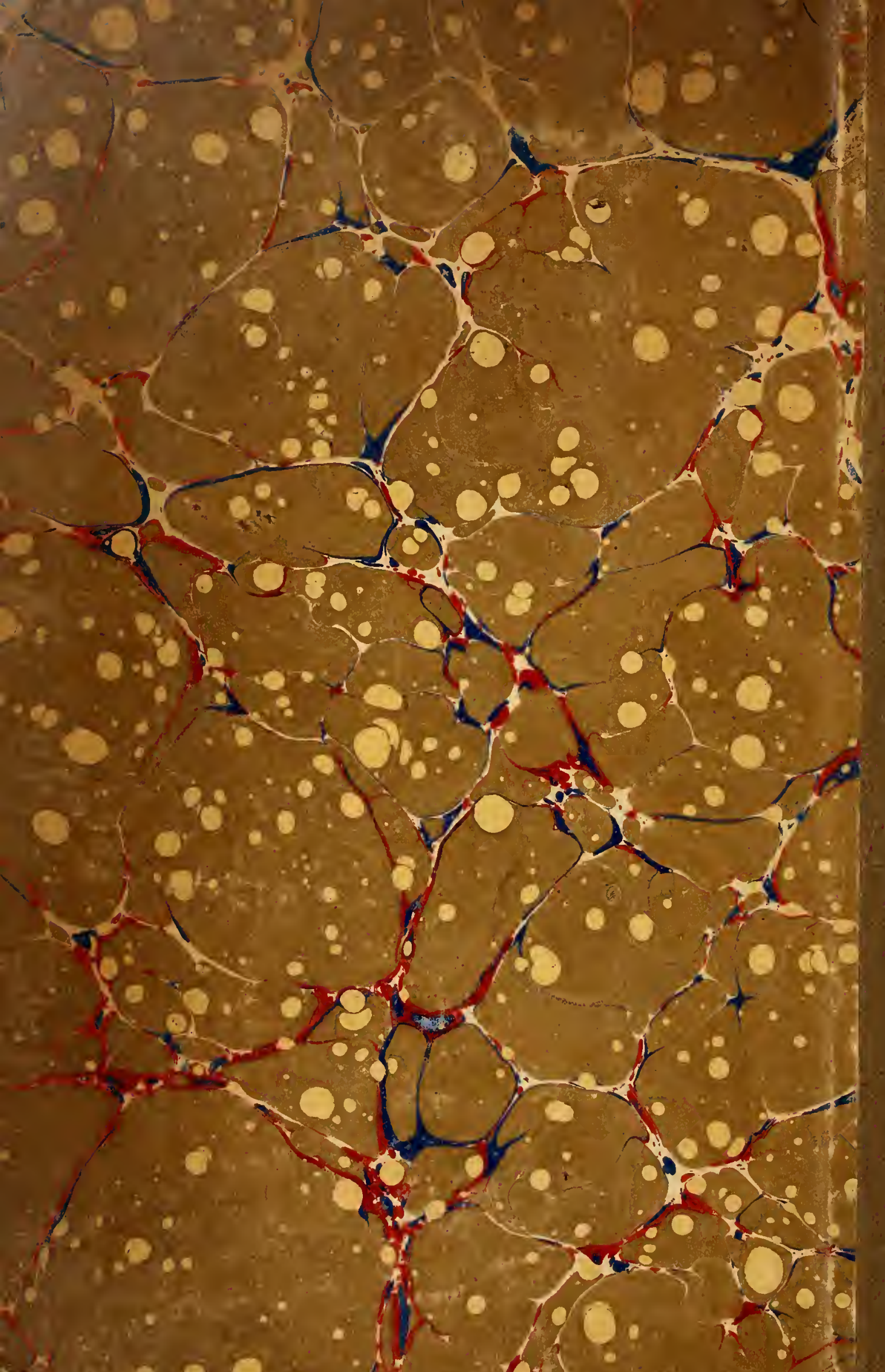

